УДК 342.72.73(477)

DOI https://doi.org/10.32837/apdp.v0i85.1876

T.І. Шинкар

\title{
ПРАВО НА ДОСТУП ДО ПУБЛІЧНОЇ ІНФОРМАЦЇ̈: ПРАВОВЕ ЗАБЕЗПЕЧЕННЯ ТА ПРОБЛЕМИ ІМПЛЕМЕНТАЦІЇ В УКРАЇНІ
}

Постановка проблеми. Після здобуття незалежності в Україні розпочато процеси будівництва демократичної правової держави, орієнтиром якої є права та свободи людини. Нагадаємо, що згідно зі ст. 3 Конституції України утвердження та забезпечення прав і свобод людини є головним обов'язком держави.

Особливого значення в сучасному інформаційному світі набуває конституційне право на доступ до інформації. Так, відповідно до ст. 34 Основного Закону України кожен володіє правом на вільний збір, збереження, використання та поширення інформації усно, письмово або в інший спосіб [1]. Крім того, порядок реалізації та гарантії забезпечення права кожного на доступ до публічної інформації, якою володіють владні та інші суб'єкти та інформації, що становить суспільний інтерес, визначені в Законі України «Про доступ до публічної інформації» [2].

Варто зазначити, що на сьогодні інформаційна сфера загалом та її складник сфера доступу до публічної інформації - набув особливого, стратегічного значення. Зростання ролі інформації в житті суспільства зумовлюе потребу зміни та переосмислення пов'язаних із нею відносин і понять, що позначається на відповідному правовому регулюванні та нормотворчій діяльності. Перш за все, це стосується права на доступ до інформації, яке пов'язане з розширенням участі громадян в управлінні державними справами, посиленнням контролю за діяльністю владних гілок тощо, що, зі свого боку, є умовами формування громадянського суспільства. Інформаційна відкритість органів публічної влади є дуже важливою, оскільки лише за наявності дієвого механізму доступу до публічної інформації суспільство може реально впливати на дії влади.

Зазначене засвідчує особливу актуальність наукового аналізу проблем, які чинять негативний вплив на ефективність реалізації владними суб'єктами законодавства у сфері доступу до публічної інформації.

Аналіз останніх досліджень і публікацій. Питання, пов'язані з поняттям права на доступ до публічної інформації, механізмом доступу до публічної інформації, стадіями адміністративного провадження щодо доступу до публічної інформації досліджували у своїх наукових працях Н. Власенко, Н. Дубина, Н. Костова, Н. Каменська, Д. Лилак, О. Майстренко, О. Нестеренко, С. Погребняк, В. Порада, Є. Теплюк, Н. Тимченко, К. Шустрова. Зацікавлення станом забезпечення права на доступ до публічної інформації також проявляли експерти громадських організацій, серед яких - I. Андрусів, Т. Дембіцька, І. Лукеря, І. Усенко та інші. Крім того, адміністративно-правові аспекти доступу громадян до публічної інформації висвітлювали у своїх дисертаційних дослідженнях Е. Аблякімова, О. Заяць, К. Маштак, Є. Ніколайчук, І. Фурман. Проте проблемні питання, пов’язані з 
юридичними колізіями щодо застосування законодавства про доступ до публічної інформації залишаються недостатньо опрацьованими та потребують подальших наукових пошуків.

Метою статті є аналіз чинних норм вітчизняного законодавства, котрі регулюють порядок реалізації права на доступ до публічної інформації, визначення проблем його імплементації та шляхів удосконалення.

Виклад основного матеріалу дослідження. Варто зазначити, що забезпечення права на доступ до публічної інформації дає можливість реалізувати низку інших прав та свобод людини, серед яких - право на доступ до суду, виборче право, право на освіту тощо. Водночас гарантією здійснення права на доступ до публічної інформації повинні бути активні дії держави, спрямовані на організаційно-правове забезпечення належного розгляду запитів на отримання інформації, а також оприлюднення суспільно важливої інформації.

Варто наголосити, що право на доступ до публічної інформації не можна ототожнювати з більш загальним правом на свободу слова та інформації, оскільки мета в цих прав однакова, проте їх функціональне призначення - різне.

Так, функція права на доступ до публічної інформації полягає, перш за все, в забезпеченні отримання особою інформації безпосередньо від органів публічної влади про їх діяльність та відомостей про себе. Щодо права на свободу інформації, то його головним призначенням є забезпечення можливості вільного пошуку та отримання будь-якої інформації, котра міститься в загальнодоступних джерелах, а також інформації про дії влади [3, с. 27]

Доволі часто в наукових дослідженнях відбувається ототожнення понять «права на інформацію» та «права на доступ до інформації. Проте вбачається, що в етимологічному значенні право на доступ до публічної інформації варто розглядати як складник більш загального права на інформацію.

До актів, які здійснюють правове забезпечення доступу до інформації, крім Конституції України, необхідно віднести Закон України «Про інформацію», Закон України «Про державну таємницю», Закон України «Про захист інформації в інформаційно-комунікативних системах». Проте проблеми реалізації конституційного права на доступ до інформації певний час породжувала відсутність нормативно-правового акта, який регулював би порядок одержання інформації від суб'єктів публічної влади.

Таким чином, у зв'язку з виникненням нагальної потреби законодавчої регламентації механізмів реалізації права кожного на доступ до публічної інформації та 3 метою забезпечення прозорості діяльності владних суб'єктів Верховна Рада України 13 січня 2011 р. прийняла Закон України «Про доступ до публічної інформації» . У ст. 1 цього Закону, зокрема, закріплене визначення поняття «публічної інформації», як відображеної та задокументованої будь-якими засобами та на будь-яких носіях інформації, яка була отримана або створена у процесі виконання суб'єктами владних повноважень своїх обов'язків, що передбачені чинним законодавством або котрі знаходиться у володінні цих суб'єктів та інших розпорядників публічної інформації, визначених законом [2]. 
Органи публічної влади, здійснюючи свої повноваження, створюють та володіють значним обсягом інформації з відкритим та обмеженим доступом, і лише чітке законодавче регулювання сприятиме отриманню зацікавленими особами потрібної їм інформації, без порушення прав та інтересів держави. 3 іншого боку, проблема доступу до публічної інформації може спричинити більш загальну проблему інформаційної відкритості та прозорості суспільних відносин у сфері діяльності органів публічної влади.

Як зазначається на офіційному сайті Міністерства юстиції України [4] станом на 17.02.20 р., законодавство про доступ до публічної інформації охоплює:

- Закон України від 13.01.2011№ 2939-VI «Про доступ до публічної інформації»;

- Указ Президента України від 05.05.2011 № 547 «Питання забезпечення органами виконавчої влади доступу до публічної інформації»;

- Постанову Кабінету Міністрів України від 25.05.2011 № 583 «Питання виконання Закону України «Про доступ до публічної інформації» в Секретаріаті Кабінету Міністрів України, центральних та місцевих органах виконавчої влади»;

- Постанову Кабінету Міністрів України від 13.07.2011 року № 740 «Про затвердження граничних норм витрат на копіювання або друк документів, які надаються за запитом на інформацію»;

- Постанову Кабінету Міністрів України від 21.11.2011 року № 1277 «Питання системи обліку публічної інформації»;

- Наказ Міністерства юстиції України від 26.05.2011 № 1434/5 «Про затвердження форм для подання запиту на отримання публічної інформації»;

- Наказ Міністерства юстиції України від 08.06.2011 № 1521/5 «Про затвердження Порядку складення та подання запитів на публічну інформацію, розпорядником якої є Міністерство юстиції України»;

- Наказ Міністерства юстиції України від 08.06.2011 № 1522/5 «Питання виконання Закону України «Про доступ до публічної інформації» в Міністерстві юстиції»;

- Наказ Міністерства юстиції України від 08.06.2011 № 1536/5 «Про затвердження Інструкції про порядок обліку, зберігання й використання документів та інших матеріальних носіїв, які містять відомості, що становлять службову інформацію в Міністерстві юстиції України»;

- Наказ Міністерства юстиції України від 04.10.2011 № 3116/5 «Про затвердження Примірного переліку видів публічної інформації, розпорядником якої є Міністерство юстиції України»;

- Наказ Міністерства юстиції України від 28.05.2014 № 846/5 «Про систему обліку публічної інформації в Міністерстві юстиції України та його територіальних органах»;

- Постанова Кабінету Міністрів України від 21.10.2015 № 835 «Про затвердження Положення про набори даних, які підлягають оприлюдненню у формі відкритих даних;

- Наказ Міністерства юстиції України від 02.03.2016 № 71/7 «Про затвердження Плану заходів із забезпечення виконання постанови Кабінету Міністрів України від 21.10.2015 № 835 «Про затвердження Положення про набори даних, які підлягають оприлюдненню у формі відкритих даних»; 
- Наказ Міністерства юстиції України від 28.03.2016 № 897/5 «Про затвердження Переліку інформації, що підлягає оприлюдненню у формі відкритих даних, розпорядником якої є Міністерство юстиції України»;

- Наказ Міністерства юстиції України від 14.07.2017 № 1277/5 «Про затвердження Переліку відомостей, які становлять службову інформацію в Міністерстві юстиції України»;

- Наказ Міністерства юстиції України від 06.11.2019 № 3412/5 «Про внесення змін до Переліку інформації, що підлягає оприлюдненню у формі відкритих даних, розпорядником якої є Міністерство юстиції України;

- Наказ Міністерства юстиції України від 06.02.2020 № 464/5 « Про затвердження Розміру фактичних витрат на копіювання або друк документів, що надаються за запитом на інформацію, розпорядником якої є Міністерство юстиції України, його територіальні органи, та Порядку відшкодування цих витрат».

Крім того, необхідно зазначити, що реалізація права на доступ до публічної інформації значною мірою залежить від способів ії отримання. Водночас для всебічної поінформованості важливим убачається узгодження отримання інформації і за інформаційним запитом, i шляхом ознайомлення з нею в загальнодоступних джерелах (офіційний сайт органу публічної влади тощо). Як слушно зауважується в юридичній літературі, належне забезпечення права на доступ до публічної інформації можливе лише за умови гарантування всіх способів отримання інформації [5, с. 77].

Розрізняють активний та пасивний спосіб реалізації права на доступ до публічної інформації. Проте серед учених відсутня єдність поглядів щодо того, які способи доступу до інформації варто зараховувати до активного чи пасивного доступу. Різняться думки і щодо термінології («спосіб» чи «форма») для позначення видів доступу до публічної інформації.

Новий тлумачний словник української мови містить такі визначення: «спосіб - певна дія, прийом або система прийомів, яка дає можливість зробити, здійснити що-небудь, досягти чогось» [6, с. 390], а «форма - тип, будова, спосіб організації чого-небудь; зовнішній вияв якого-небудь явища, пов'язаний із його сутністю, змістом» [6, с. 665]. 3 огляду на наведене деякі фахівці вважають, що для позначення видів доступу до публічної інформації запитувачів цієї інформації доцільно вживати термін «спосіб», а для розпорядників публічної інформації, до компетенції яких належить забезпечення такої інформації, варто застосовувати поняття «форма» [5, с. 78$]$.

Хоча пошуки шляхів належної імплементації права на доступ до інформації мають доволі довгу історію, значне підвищення зацікавленості цим важливим питанням можна спостерігати в останні два десятиріччя. Сьогодні більш ніж у 80 країнах світу прийняті закони, які врегульовують відносини між особою та владою в цій сфері. Принцип доступу громадськості до інформації в найширшому розумінні означає, що громадяни та засоби масової інформації (ЗМІ) володіють правом на отримання інформації про діяльність органів державної влади та місцевого самоврядування. Із теоретичного погляду, цей принцип має тісний зв'язок із принципом свободи преси, суть якого полягає у праві вільного розповсюдження правдивої інформації в газетах та книгах [7, с. 88]. 
Головна суть обох зазначених принципів полягає в максимальній відкритості інформації. Інакше кажучи, можливість приховування інформації від громадськості допускається лише тоді, коли є нагальна необхідність запобігти нанесенню шкоди правам та законним інтересам особи та держави.

Наголошуючи на важливості врахування міжнародного та зарубіжного досвіду вирішення проблеми забезпечення доступу до публічної інформації, В. Порада, зокрема, зазначає, що "аналіз міжнародно-правового регулювання доступу до публічної інформації, а також досвіду окремих зарубіжних країн щодо забезпечення громадянам доступу до публічної інформації дозволив стверджувати, що правове регулювання права громадян на доступ до публічної інформації є однією 3 найважливіших гарантій становлення будь-якого демократичного суспільства. Процес доступу до публічної інформації від їі носія (власника) до користувача може відбуватись як безпосередньо, так і за допомогою інформаційних посередників. Роль такого посередника виконують найчастіше засоби масової інформації. Загалом досвід країн, які прийняли закони про доступ до публічної інформації, свідчить про позитивний вплив таких законодавчих змін на реалізацію громадянами основоположних прав, підвищення ефективності діяльності органів влади, а також зменшення ризиків корупції в діяльності інформативної сфери» [8, с. 325].

Більшість експертів, котрі займаються проблематикою доступу до інформації, відзначають важливість та актуальність Закону України «Про доступ до публічної інформації», прийняття якого стало вагомим кроком на шляху гарантування та законодавчого забезпечення права кожного на вільне збирання, зберігання, використання та поширення інформації, яке закріплене в Основному Законі України, а також для збільшення прозорості та відкритості роботи органів публічної влади. Як уже було зазначено, суть права на доступ до інформації полягає в тому, що кожному гарантоване право отримувати безпосередньо від органів державної влади та органів місцевого самоврядування, а також відповідних посадових і службових осіб необхідні офіційні документи й іншу важливі інформацію про поточну діяльність цих органів.

Водночас Закон не позбавлений певних недоліків, про що зазначається в юридичній літературі. Так, Н. Тимченко вказує на низку суперечностей цього Закону, якими можуть скористатись владні структури для обгрунтування відмови в наданні інформації. Зокрема, автор згадує ст. 6 Закону, де поряд з іншими видами інформації з обмеженим доступом указана і службова інформація. Проте, на їі думку, зарахування службової інформації до інформації з обмеженим доступом є дещо дискусійним. Це питання ускладнюється й відсутністю в Україні правового інституту, котрий визначав би порядок, підстави та умови надання інформації із грифом «службова інформація» [9, с. 39-40].

Крім того, на думку деяких фахівців, далеко не кожен громадянин має достатній рівень правової обізнаності для усвідомлення всього обсягу своїх прав на доступ до інформації, яка вважається, за законодавством України, публічною. Так, характеризуючи проблему імплементації правових норм, котрі регулюють порядок доступу до публічної інформації, В. Кирильчук, зокрема, зазначає, що «часто суб'єкти владних повноважень не відрізняють запит на публічну інформацію та 
звернення громадян (які мають різну юридичну природу), що і собі ускладнює механізм реалізації права громадян на доступ до публічної інформації. Ці поняття відрізняються між собою, перш за все, нормативно-правовим регулюванням. Так, питання практичної реалізації громадянами права на звернення регулюється Законом України «Про звернення громадян», а запити на інформацію - Законом України «Про доступ до публічної інформації». Ці категорії мають абсолютно різний зміст: запит на інформацію - це прохання особи до розпорядника інформації надати публічну інформацію, котра знаходиться в його володінні» [10].

Ще однією серйозною проблемою щодо реалізації права на доступ до публічної інформації є мова викладу цього чи іншого документа. Часто незнання мови є перешкодою для розуміння нормативно-правових актів, різноманітних документів. Як слушно зазначають фахівці, мова та практика виступають продуктами контексту. Якщо людина спеціально не займається поглибленим вивченням юридичної практики, вона нерідко не зможе зрозуміти логіки та змісту тих чи інших нормативно-правових рішень [7, с. 91].

Також на окрему увагу у сфері доступу до публічної інформації заслуговує проблема правового нігілізму, яка є однією з головних причин неналежного виконання вимог Закону України «Про доступ до публічної інформації» суб’єктами владних повноважень.

Нагадаємо, що сутність правового нігілізму у традиційному розумінні полягає в негативному ставленні до права, зневірі в його можливості вирішувати нагальні проблеми відповідно до вимог соціальної справедливості.

Водночас уважаємо, що виникнення правового нігілізму у сфері доступу до публічноїінформаціїпевною мірою спричинено самим законодавством. Так, у профільному Законі не врегульоване питання зловживання правом на інформацію, котра породжує ситуацію, коли суб'єкти владних повноважень не зацікавлені належним чином забезпечувати виконання законодавства про доступ до публічної інформації.

Таким чином, через відсутність механізму попередження зловживань у процесі реалізації права на інформацію виникає певний спротив розпорядників інформації щодо ефективного виконання законодавчих вимог у сфері доступу до інформації.

Переконані, що подолання наявного правового нігілізму сприятиме розбудові правової держави, підвищенню рівня правової свідомості та культури населення, утвердженню принципу верховенства права. У науковій літературі виокремлюють такі основні групи заходів боротьби із правовим нігілізмом:

- заходи політичного характеру, які безпосередньо пов'язані з подоланням факторів, що перешкоджають розвитку правової держави;

- соціально-економічні заходи;

- заходи культурного, духовного, морального характеру [11, с. 57].

Крім того, І. Демченко до способів подолання явища правового нігілізму відносить: підвищення правової або іншої спеціальної освіти; обов’ язкове проходження кожним новим нормативно правовим актом грунтовної правової експертизи; залучення до законотворчої роботи науковців, визнаних спеціалістів у галузі права; забезпечення доступу громадськості до законопроєктної роботи; підвищення якості виховання та освіти громадян, приведення її до світових стандартів й ідеалів [12]. 
Висновки. Отже, Закон України «Про доступ до публічної інформації» визначив правові механізми реалізації права на отримання інформації, охоплюючи ту, яка стосується діяльності владних органів, прийняття нових нормативних актів тощо. Попри певні недоліки, Закон містить низку новацій, зокрема, він базується на ідеї відкритості публічної інформації, доступ до якої здійснюється на основі таких принципів:

1) прозорості та відкритості діяльності суб’єктів владних повноважень;

2) вільного отримання та поширення інформації, крім обмежень, передбачених законом;

3) рівноправності, незалежно від ознак раси, кольору шкіри, політичних, релігійних та інших переконань, статі, етнічного та соціального походження, майнового стану, місця проживання, мовних або інших ознак.

Водночас необхідно врахувати, що невиконання вимог чинного законодавства нівелює всі зусилля нормотворців щодо належного врегулювання суспільних відносин та призводить до виникнення розбіжностей між нормативно-правовими приписами та діяльністю, пов'язаною з їх реалізацією.

На наше переконання, подальше послідовне впровадження в життя (імплементація) правових норм у сфері доступу до публічної інформації чинитиме позитивний вплив на розвиток громадянського суспільства, зростання активності громадян та підвищення ефективності та відкритості діяльності органів публічної влади в Україні.

\section{Jimepamypa}

1. Конституція України від 28.06.1996 р. Відомості Верховної Ради України. 1996. № 30. Ст. 141.

2. Про доступ до публічної інформації: Закон України від 13 січня 2011 року № 2939-VI. Електронний ресурс. Режим доступу: https://zakon.rada.gov.ua/laws/show/2939-17. Дата звернення $27.04 .20 \mathrm{p}$.

3. Нестеренко О. Конституційне право на доступ до інформації: сутність, зміст та обсяг. Юридична Україна. 2008. № 3. С. 26-32.

4. Міністерство юстиції України. Доступ до публічної інформації (оновлено 17.02 .2020 р.) Електронний ресурс. Режим доступу: https://minjust.gov.ua/publ_info. Дата звернення -28.04 .20 p.

5. Скочиляс-Павлів О. Способи здійснення права на доступ до публічної інформації. Вісник Національного університету «Львівська політехніка». Серія: Юридичні науки : збірник наукових праць. 2015. № 813. С. $76-80$.

6. Новий тлумачний словник української мови у трьох томах / укладачі В. Яременко, О. Сліпушко. Т. 3: П-Я. Київ : Аконіт, 2008. 864 с.

7. Костова Н. Доступ до публічної інформації: порівняльний аналіз українського законодавства і країн Європейського Союзу. Visegrad journal on human rights, № 2/2, 2016, С. 88-92.

8. Порада В. Міжнародно-правові стандарти доступу громадян до публічної інформації. Наукові записки Львівського університету бізнесу та права. 2014. № 12. С. 322-325.

9. Тимченко Н. Правовий механізм доступу до публічної інформації: сучасний стан та перспективи. Правовий вісник Української академії банківської справи. 2012. С. 39-42

10. Кирильчук В. Актуальні проблеми доступу до публічної інформації. Електронний ресурс. Режим доступу: http://3222.ua/article/aktualn_problemi_dostupu_do_publchno_nformats.htm.

11. Бурдоносова М. Правовий нігілізм: сутність та основні риси. Часопис Київського університету права. 2008. № 4. С. 53-58

12. Демченко I. Правовий нігілізм в Україні. Шляхи його подолання. Наукові конференції. Соиіум. Наука. Культура. Режим доступу: http://intkonf.org/demchenko-is-pravoviy-nigilizm-v-ukrayinishlyahi-yogo-podolannya/. 


\section{Анотація}

Шинкар T. I. Право на доступ до публічної інформації: правове забезпечення та проблеми імплементації в Україні. - Стаття.

Проаналізовано поняття права на доступ до публічної інформації, його нормативно-правове забезпечення в Україні. Зокрема зазначається, що, відповідно до ст. 34 Конституції України, кожен володіє правом на вільний збір, збереження, використання та поширення інформації усно, письмово або в інший спосіб. Водночас наголошується, що право на доступ до публічної інформації не можна ототожнювати з більш загальним правом на свободу слова та інформації, оскільки мета в цих прав однакова, проте їх функціональне призначення - різне.

Також указується, що до актів, котрі здійснюють правове забезпечення доступу до публічної інформації, крім Конституції України, відносять Закон України «Про інформацію», Закон України «Про державну таємницю», Закон України «Про захист інформації в інформаційно-комунікативних системах» тощо. Проте правовий механізм реалізації конституційного права на доступ до інформації та порядок одержання інформації від суб'єктів публічної влади визначені в Законі України «Про доступ до публічної інформації» від 13 січня 2011 р.

Зазначається, що органи публічної влади, здійснюючи свої повноваження, володіють значним обсягом інформації з відкритим та обмеженим доступом, і лише чітке законодавче регулювання сприятиме отриманню зацікавленими особами потрібної їм інформації. 3 іншого боку, проблема доступу до публічної інформації може спричинити більш загальну проблему інформаційної відкритості та прозорості суспільних відносин у сфері діяльності владних структур.

Крім того, у статті окреслюються проблеми імплементації вітчизняного законодавства про доступ до публічної інформації та шляхи їх вирішення. Зокрема, акцентується увага на недостатньому рівні правовоїобізнаності громадян, а також напроблемі правового нігілізму, щоєоднією з головних причин неналежного виконання владними суб'єктами вимог Закону України «Про доступ до публічної інформації» .

Указується на засоби подолання цих негативних явищ, основними серед яких убачається підвищення правової освіти населення, обов'язкове проходження кожним новим нормативно-правовим актом належної правової експертизи, залучення до законотворчої роботи науковців, визнаних спеціалістів у галузі права, забезпечення доступу громадськості до законопроєктної роботи.

Ключові слова: публічна інформація, доступ до інформації, правове забезпечення, імплементація, зарубіжний досвід.

\section{Summary}

Shynkar T. I. The right to access public information: legal enforcement and implementation problems in Ukraine. - Article.

The article analyzes the concept of the right to access public information, its legal and regulatory enforcement in Ukraine. In particular, it is defined that according to article 34 of the Constitution of Ukraine everyone has a right to free collection, conservation, use and distribution of information verbally, in writing or in another way. It is emphasized that the right to access public information cannot be equated with more general right to freedom of expression and information since the goal of these rights is the same, yet its functional purpose is different.

Moreover, the article identifies the acts, in addition to the Constitution of Ukraine, that exercise legal enforcement of the access to public information such as the Law of Ukraine "On information", the Law of Ukraine "On state secret", the Law of Ukraine "On protection of information in information and communication systems" etc. Yet, legal mechanism of implementation of constitutional right to access the information and the procedure for obtaining information from public law authorities is defined in the Law of Ukraine "On access to public information" from January 13, 2011.

It is noted that public authorities, in exercising their powers, have a very large amount of information with open and limited access, and only clear legislation will help stakeholders obtain the information they need. On the other hand, the problem of access to public information may lead to a more general problem of information openness and transparency of public relations in the field of government.

In addition, the article outlines implementation problems of national legislation on access to public information and the means of its resolution. In particular, it is emphasized that there is insufficient level of legal awareness of citizens as well as there is a problem of legal nihilism which is one of the main reasons of improper execution by governmental authorities of the requirements of the Law of Ukraine "On access to public information".

The means of overcoming these negative phenomena are noted, among which the primary ones are improvement of legal education of the population, mandatory completion of appropriate legal expertise by each new legal act, engagement of scientists and recognized experts in the field of law in lawmaking, enforcement of the access of public to lawmaking.

Key words: public information, access to information, legal enforcement, implementation, foreign experience. 